УДК 619:616.233-002-091:636.52

(C) 2013

Борисевич Б. В., доктор ветеринарних наук, професор,

Лісова В. В., кандидат ветеринарних наук,

Kриштоп М. C., аспірант (науковий керівник-доктор ветеринарних наук Б. В. Борисевич)

Національний університет біоресурсів і природокористування України

\title{
МІКРОСКОПІЧНІ ЗМІНИ В НИРКАХ І МІОКАРДІ КУРЕЙ ЗА ІНФЕКЦЙНОГО ЛАРИНГОТРАХЕЇТУ
}

\section{Рецензент - доктор ветеринарних наук, професор В. Т. Хомич}

Представлено результати гістологічних досліджень нирок і міокарду курей, які загинули від інфекиійного ларинготрахеїту. Встановлено, щуо в нирках реєструються розлади кровообігу в вигляді розширення та переповнення кров'ю кровоносних судин строми органа, екстракапілярний серозний гломерулонефрит $і$ дистрофічні зміни та руйнування епітелію канальиів. У міокарді провідною патологією була зерниста дистрофія м'язових клітин. Окрім того реєструвалися фрагментація та дезорієнтація м'язових волокон. У епікарді та ендокарді мікроскопічних змін не було.

Ключові слова: кури, інфекиійний ларинготрахеїт, патолого-анатомічна діагностика, мікроскопічні зміни, нирки, міокард.

Постановка проблеми. Інфекційний ларинготрахеїт - інфекційна хвороба курей, спричинена герпес вірусом. Інфекційний ларинготрахеїт реєструється на всіх континентах і в більшості країн світу. Хворіють кури будь-якого віку й породи, проте найбільш сприйнятливим $є$ молодняк віком до одного року. В стаціонарно неблагополучних господарствах курчата хворіють із 25-30-денного віку, хворіють також індички та пташенята фазанів [2]. У гострих випадках у хворої птиці уражуються верхні дихальні шляхи - гортань і трахея, що $€$ характерною ознакою цієї хвороби. Проте в підгострих та хронічних випадках клінічні ознаки інфекційного ларинготрахеїту й патолого-анатомічні зміни суттєво не відрізняються від таких у разі хвороб органів дихання іншої етіології [7].

Аналіз останніх досліджень і публікацій, у яких започатковано розв'язання проблеми. У доступній літературі описано макроскопічні зміни в курей за інфекційного ларинготрахеїту, а також мікроскопічні зміни в гортані, трахеї та (менш детально) в легенях [5, 6]. В інших органах i тканинах мікроскопічні зміни не описані або описані неповно. Проте в ході патологоанатомічної діагностики - особливо при диференціації даної хвороби від інших респіраторних захворювань курей - необхідно враховувати як макроскопічні, так і мікроскопічні зміни в усіх органах і тканинах. Окрім того, знання цих змін необхідне для повного розуміння патогенезу хвороби, який варто враховувати, розробляючи методи ії лікування та профілактики.

Мета дослідження - встановити мікроскопічні зміни в нирках і міокарді курей, які загинули від інфекційного ларинготрахеїту.

Завдання дослідження: провести гістологічне дослідження нирок і міокарду курей, які загинули від інфекційного ларинготрахеїту.

Матеріали і методи досліджень. Робота виконувалася на базі Миронівської птахофабрики. Діагноз на інфекційний ларинготрахеїт встановлювали комплексно, з урахуванням епізоотологічних даних, клінічних ознак хвороби, патологоанатомічних змін і результатів лабораторної діагностики (Біотестлабораторія, м. Київ, метод імуноферментного аналізу). Патолого-анатомічний розтин 23-х трупів загиблої птиці різного віку виконували методом часткової евісцерації в загальноприйнятій послідовності [3]. У ході проведення патолого-анатомічного розтину для гістологічних досліджень відбирали шматочки з різних ділянок нирок і серця. Відібрані шматочки фіксували в $10 \%$ водному нейтральному розчині формаліну й після зневоднення в етанолах зростаючої концентрації через хлороформ заливали в парафін. Зрізи товщиною 7-10 мкм одержували за допомогою санного мікротому [4]. Для виявлення гістологічної будови органів і тканин проводили фарбування зрізів гематоксиліном Караці та еозином [1].

Результати досліджень. У результаті проведення гістологічних досліджень нирок курей, які загинули від інфекційного ларинготрахеїту, нами було встановлено, що кровоносні судини строми (переважно вени, венули та капіляри) розширені, переповнені кров'ю. В усіх ділянках канальців більшість епітеліальних клітин перебувало в стані зернистої дистрофії. Частина епітеліоцитів частково чи повністю втрачала зв'язок із базальною мембраною канальців. Клітини, що повністю втрачали такий зв'язок, злу- 


\section{ВЕТЕРИНАРНА МЕДИЦИНА}

щувалися в просвіт канальців. Частина епітеліальних клітин канальців руйнувалась. В одних випадках нами було знайдено руйнування апікальної частини цитоплазми епітеліоцитів із наступним відділенням іï фрагментів у просвіт канальців. В інших випадках відбувався розрив цитоплазматичної оболонки з частковим лізисом різних ділянок (апікальних, базальних та навколоядерних у різних комбінаціях) цитоплазми 3 наступним частковим або повним лізисом ядра. У багатьох випадках повний лізис ядра виявлявся в клітинах лише 3 частковим лізисом цитоплазми. У більшості ниркових тілець реєструвався серозний гломерулонефрит, який характеризувався специфічними для цього виду патології нирок мікроскопічними змінами. В просвіті капсули БоуменаШумлянського накопичувався серозний ексудат, що супроводжувалося збільшенням як розмірів ниркових тілець, так і просвіту порожнини їх капсули. До того ж у більшості випадків капілярне сплетіння ниркового тільця більше чи менш помітно відсувалося на один із його полюсів і стискалось ексудатом, внаслідок чого його розміри зменшувалися. Самі ниркові тільця 3 такого роду змінами зберігали округлу або набували дещо овальної форми. У частині випадків накопичення ексудату було нерівномірним, у результаті чого порожнина капсули Боумена-Шумлянського нерівномірно розширювалась, а ниркові тільця набували неправильної форми круга чи овалу з багатьма виступами й западаннями поверхні різних розмірів $\mathrm{i}$ ступеню. У багатьох ниркових тільцях встановлено часткову чи повну втрату зв'язку подоцитів 3 ендотеліальними клітинами капілярів, унаслідок чого капілярні сплетіння таких ниркових тілець вогнищево чи дифузно виглядали дещо розрихленими. У частині ниркових тілець просвіт на окре-

\section{БІБЛІОГРАФІЯ}

1. Горальський Л. П., Хомич В. Т., Кононський О. I. Основи гістологічної техніки i морфофункціональні методи дослідження у нормі та при патології. - Житомир : Полісся, 2005. - 288 с.

2. Довідник лікаря ветеринарної медицини / П. І. Вербицький, П. П. Достоєвський. - К. : Урожай, 2004. - 1280 с.

3. Зон Г. А., Скрипка М. В., Івановська Л. Б. Патологоанатомічний розтин тварин. - Донецьк: ПП Глазунов Р. О., 2009. - 189 с.

4. Лили Р. Патологическая техника и практическая гистохимия. - М. : Мир, 1969. - 640 с.

5. Bagust T. J., Calnek B. W., Fahey K. J. Gallid-1 мих ділянках капілярів настільки сильно розширювався, що ставав добре помітним навіть за незначних збільшень мікроскопа. Слід зауважити, що таке розширення було нерівномірним, внаслідок чого просвіт капілярів мав неправильну форму, а в капілярах були відсутні клітини крові.

Таке розширення просвіту капілярів ниркових тілець при відсутності в них клітин крові, на нашу думку, могло зумовлюватися застоєм крові в поєднанні $з$ порушенням фільтрації складових компонентів первинної сечі, що призводило до накопичення рідкої частини (плазми) крові на окремих ділянках капілярного сплетіння ниркових тілець. У міокарді курей, які загинули від інфекційного ларинготрахеїту, спостерігали розширення й переповнення кров'ю судин та дифузний набряк строми й м'язової тканини. В останній внаслідок набряку виникало розшарування пучків м'язових волокон. Окрім того реєструвалися зерниста дистрофія міокардіоцитів та руйнування частини м'язових клітин. Набряк i руйнування м'язових клітин призводили до фрагментації й дезорієнтації м'язових волокон. У епікарді та ендокарді мікроскопічних змін не виявлено.

\section{Висновки:}

1. У нирках курей, які загинули від інфекційного ларинготрахеїту, реєструються розлади кровообігу, ексракапілярний серозний гломерулонефрит і дистрофічні зміни та руйнування епітелію канальців.

2. У міокарді провідною патологією була зерниста дистрофія м'язових клітин.

3. У подальшому необхідно провести гістологічні дослідження інших органів і тканин курей, які загинули від інфекційного ларинготрахеїту, 3 метою встановлення в них характеру патоморфологічних змін.

herpesvirus infection in the chicken. 3. Reinvestigation of the pathogenesis of infectious laryngotracheitis in acute and early post-acute respiratory disease // Avian Diseases, 1986. Vol. 30. - N 2. - P. 30-39.

6. Bagust T. J., Johnson M. A. Avian infectious laryngotracheitis: Virus-host interactions in relation to prospects for eradication. // Avian Pathology, 1995. - Vol. 24. - N 4. - P. 373-391.

7. Hidalgo $H$. Infectious Laryngotracheitis: A Review // Revista Brasileira de Ciência Avícola, 2003. - Vol. 5. - N 3. - P. 157-168. 